Cahiers $d u$ MONDE RUSSE

\section{Cahiers du monde russe}

Russie - Empire russe - Union soviétique et États indépendants

$46 / 1-2 \mid 2005$

La Russie vers 1550

\title{
ОТНОШЕНИЯ ПРАВИТЕЛЯ И ЗНАТИ В СЕВЕРОВОСТОЧНОЙ РУСИ
}

Peter S. STEFANOVIC

\section{OpenEdition \\ Journals}

Édition électronique

URL : https://journals.openedition.org/monderusse/8802

DOI : $10.4000 /$ monderusse. 8802

ISSN : $1777-5388$

Éditeur

Éditions de l'EHESS

Édition imprimée

Date de publication : 1 janvier 2005

Pagination : 277-284

ISBN : 2-7132-2055-6

ISSN : $1252-6576$

\section{Référence électronique}

Peter S. STEFANOVIC, « Отношения правителя и знати в СевероВосточной Руси », Cahiers du monde russe [En ligne], 46/1-2 | 2005, mis en ligne le 01 janvier 2007, consulté le 03 septembre 2022 URL : http://journals.openedition.org/monderusse/8802; DOI : https://doi.org/10.4000/monderusse. 8802 
chercher : repérer : avancer

Cet article est disponible en ligne à l'adresse :

http://www.cairn.info/article.php?ID REVUE=CMR\&ID NUMPUBLIE=CMR 461\&ID ARTICLE=CMR 4610277

\section{Отношения правителя и знати в Северо-Восточной Руси}

par Peter S. STEFANOVIC

| Editions de l'EHESS | Cahiers du monde russe

2005/1-2 - Vol 46

ISSN 1252-6576 | ISBN 2713220556 | pages 277 à 284

Pour citer cet article :

- S. STEFANOVIC P., Cahiers du monde russe 2005/1-2, Vol 46, p. 277-284.

Distribution électronique Cairn pour les Editions de l'EHESS.

(C) Editions de l'EHESS. Tous droits réservés pour tous pays.

La reproduction ou représentation de cet article, notamment par photocopie, n'est autorisée que dans les limites des conditions générales d'utilisation du site ou, le cas échéant, des conditions générales de la licence souscrite par votre établissement. Toute autre reproduction ou représentation, en tout ou partie, sous quelque forme et de quelque manière que ce soit, est interdite sauf accord préalable et écrit de l'éditeur, en dehors des cas prévus par la législation en vigueur en France. Il est précisé que son stockage dans une base de données est également interdit. 
ПЕТР С. СТЕФАНОВИЧ

\title{
ОТНОШЕНИЯ ПРАВИТЕЛЯ И ЗНАТИ В СЕВЕРО-ВОСТОЧНОЙ РУСИ B XIV - HAЧ. XVI B.
}

\author{
Крестоцелование как клятва верности ?
}

В науке сегодня нет ясного и общепризнанного представления о том, на каких основаниях и по каким принципам строилась служба князю бояр и других представителей высших социальных слоёв в эпоху становления единого Русского государства. Вслед неоднозначным и довольно противоречивым показаниям источников в историографии высказываются мнения спорные и трудно согласующиеся между собой. Например, ещё в дореволюционной науке довольно твёрдо установился взгляд, что издревле служба бояр и других представителей русской знати князьям была вольной, основанной на договоре. Исходили при этом из известного пункта княжеских договорных грамот «А боярам и слугам межи нас вольным воля», гарантировавшего знати «право отъезда», т. е. право уйти с княжеской службы по своей воле. Только в XV в. московское правительство, согласно этому взгляду, повело целенаправленную борьбу против этой вольности ${ }^{1}$. Между тем с такой концепцией трудно примирить выводы тех исследователей, которые настаивают на том, что в средневековой Руси в отношениях правителя (князя) и знати всегда главенствующим был принцип (безусловной) верности, коренящийся ещё в дружинном этосе ${ }^{2}$.

1. Такие идеи проводили, например, В. И. Сергеевич (см. ниже) и М. А. Дьяконов (например, в работе Очерки общественного и государственного строя Древней Руси, М.-Л., 1926).

2. См., например: Н. П. Загоскин, Очерк организации и происхождения служилого сословия в допетровской Руси, Казань, 1875, с. 24-28. Среди новейших работ ср. H. Rüß, Herren und Diener: Die soziale und politische Mentalität des russischen Adels 9.-17. Jh., Köln, 1994, S. 472. 
В ряду нерешённых вопросов в рамках парадигмы «договор-верность в отношениях князя и знати» стоит вопрос о том, существовала ли в средневековой Руси клятва верности, которая приносилась при вступлении на службу князю. Прямых и бесспорных данных о такого рода клятвах (как и, например, о предполагаемых «договорах» между князем и знатными людьми) источники не содержат. Однако известные учёные предполагают нечто подобное, основываясь на так называемых крестоцеловальных записях XV-XVI вв., которые московские государи брали со служилых князей и бояр в качестве гарантии верной службы, а также на летописных упоминаниях о крестоцеловании бояр какого-либо города или земли тому или иному князю. Например, В. И. Сергеевич, ссылаясь на такие летописные известия кон. XIV-XV в., утверждал: «приказываясь на службу, бояре и слуги вольные давали клятвенное обещание верности». Рассуждая далее о борьбе московских князей с правом боярского отъезда, Сергеевич фактически ставил крестоцеловальные записи в связь с традицией этого «клятвенного обещания верности» ${ }^{3}$.

Хотя утверждение В. И. Сергеевича вызвало определённые сомнения ${ }^{4}$, к нему позднее присоединился такой видный знаток русского средневековья как С. Б. Веселовский, который называл записи «религиозным подкреплением договора о службе» между князем и боярином или просто «формой присяги служилых людей» ${ }^{5}$ М. Н. Тихомиров, также будучи убеждён в договорном характере отношений князя и его бояр, допускал даже сравнение крестоцелования (подкреплённого записью) с западноевропейским оммажем ${ }^{6}$. Современный исследователь, ссылаясь на записи, заявляет, что

идеология политического согласия, гармонии и единства в отношениях правителя и знати закреплялась в клятвах, которые с древности приносились в устной форме, с христианизацией - посредством крестоцелования и перед евангелием с поднятой правой рукой ${ }^{7}$.

Обратимся к источникам и посмотрим, насколько обоснованными выглядят приведённые суждения. Нас интересует прежде всего, существовала ли на

3. В. И. Сергеевич, Древности русского права, т. 1, СПб., 1909, с. 378, 387-388.

4. Так, например, писал Н. П. Павлов-Сильванский: «Мы не думаем, чтобы бояре, отъезжая, нарушали клятву, данную князю, чтобы, приказываясь в службу, они целовали крест служить верно, как полагает проф. Сергеевич [...]. Это было бы добровольным отказом от своего права, на который едва ли соглашались бояре по общему правилу при поступлении на службу» («Государевы служилые люди», Н. П. Павлов-Сильванский, Государевы служилье люди: Люди кабальные, М., 2001, с. 118). Как видно, Павлов-Сильванский, отрицая существование на Руси боярского крестоцелования с обязательством верной службы, лишь последовательно проводит идею о господстве до XV в. вольной службы знати князю.

5. С. Б. Веселовский, Исследования по истории класса служильх землевладельцев, М., 1969, с. 251, 472.

6. М. Н. Тихомиров, Российское государство XV-XVII веков, М., 1973, с. 327.

7. H. Rüß, op. cit., S. 277. 
Руси в XIV-XVI вв. клятва верности служилого человека князю, и если - да, то в какой форме и сопоставима ли она с аналогичными явлениями в Западной Европе.

Корпус сохранившихся крестоцеловальных записей включает 14 документов. Семь из них сопровождаются поручными записями, в которых бояре и князья крупными суммами поручаются за того боярина или князя, который целовал московскому государю крест ${ }^{8}$. Крестоцеловальная запись называется в самом тексте «укрепленой грамотой», а оформляется как жалованная грамота: по челобитью боярина (князя) и по поручительству митрополита и других высших церковных иерархов государь «жалует» «своего слугу» (опального) - прощает ему «вину» и «отдает нелюбье». Провинившийся (по летописям известно, что «вина» состояла в намерении отъехать из Москвы в Литву) обязывался служить «до живота своего» государю и его детям, не «мыслити» никакого «лиха» против государя, а если услышит, что кто-либо замысливает такое «лихо», сообщать о таковых злоумышленниках. В конце записи говорилось, что опальный боярин (князь) «крепости деля» целовал крест и дал «на себя сию свою грамоту за подписью и печатью» митрополита. В поручных записях тоже упоминается о «вине» опального перед государем и об обязательстве его в дальнейшем верно служить.

Древнейшая крестоцеловальная запись датируется 1474 г. (дана князем Даниилом Холмским, заподозренном в намерении отъехать в Литву, великому князю Ивану Васильевичу), последняя - 1582 г. В митрополичьем формулярнике сохранился также извод (образец) «грамоты жаловальной князя великого к его бояром о их вине», согласно которой провинившийся перед государем боярин при поручительстве митрополита получает прощение, обязавшись верно служить «до своего живота» и поцеловав крест «крепости деля». С незначительными расхождениями текст этой грамоты соответствует позднейшим крестоцеловальным записям ${ }^{9}$. Составление этого формуляра датируют 1448-1471 гг., и таким образом обычай закрепления в специальной грамоте акта крестоцелования, совершенного для подтверждения обязательства верной службы великому князю, нельзя возводить ко времени ранее начала XV в.

Каким образом употреблялось крестоцелование до нач. XV в., особенно в отношениях правителя и знати?

8. Собрание государственных грамот и договоров, т. 1, М., 1813, № 103/104, 146, $149,152 / 153,157,159,162,165 / 166,172,175 / 176 / 177,182 / 184,189 / 190 / 191$, 196/197/198, 201.

9. Русский феодальный архив, ч. 1, М., 1986, № 46, с. 175-176. Ср. комментарий издателей: там же, ч. 5, М., 1992, с. 989-991. Нахождение «грамоты» в архиве митрополичьей кафедры объясняется, очевидно, тем, что митрополит был главным поручителем за опальных сановников и принимал у них крестоцелование. 
Этот обряд широко применялся в юридической и политической практике Русского государства с древнейших времен. Новгородские берестяные грамоты свидетельствуют, что к совершению обряда прибегали при заключении частных договоров и коммерческих сделок. В сфере права крестоцелование использовалось как клятва в суде, подтверждающая верность показаний. В летописях, начиная с сер. XI в., постоянно встречаются упоминания крестоцелования для скрепления разного рода договорённостей в среде Рюриковичей, а также между ними и представителями русских городов, послами и правителями других государств. Хотя средневековая Русь знала и другие формы клятвы (причём довольно разнообразные, имеющие как дохристианское происхождение, так и христианское содержание), преобладающим в политической сфере было именно крестоцелование, а к XV в. оно стало практически единственным терпимым церковью (впрочем, с определёнными ограничениями) способом скрепления обещаний и высказываний. Однако нет ни одного указания на то, что этот обряд использовался знатными людьми при заключении каких-либо «договоров» о службе между ними и князьями.

Представители знати целовали крест либо как частные лица (в суде, при заключении торговых сделок и т. п.), либо коллективно как участники многосторонних политических договоров, которые князья заключали между собой или с горожанами. Чаще всего такие договоры заключались князьями перед смертью для закрепления такого порядка престолонаследия, который так или иначе отличался от традиционного. Кроме того, в XII-XIV вв. крестоцелованием скреплялись договоры князя и городской общины, во главе которой стояло местное боярство, тогда, когда город переходил к этому князю из-под власти другого (разумеется, в тех случаях, когда речь шла о достаточно крупном городе, и когда не было прямого военного захвата).

Летописцы много пишут о крестоцеловании, но всегда только в контексте отношений Рюриковичей. Обряд призван хранить «братскую любовь» в их среде. Предательство князя знатным, приближённым к князю человеком осуждается летописцами либо как нарушение «братней любви» Рюриковичей, либо как отпадение от Богом установленной власти ${ }^{10}$. Однако в древнейших летописях нет ясно и чётко выраженного осуждения предателя именно за то, что он нарушил клятву верности - будь то крестное целование или какая-либо другая клятва ${ }^{11}$.

10. Подробнее о крестоцеловании в Древней Руси см. наши публикации: П. С. Стефанович, «Религиозно-этические аспекты отношений князя и знати в домонгольской Руси», Отечественная история, 2004, № 1; Он же, «Крестоцелование и отношение к нему церкви в домонгольской Руси», Средневековая Русь, вып. 5, М., 2004. Там же указана литература предмета.

11. Единственным исключением можно было бы считать летописное известие о присоединении Нижнего Новгорода к Москве в 1392 г., где рассказывается о том, 
Впервые упоминание о крестоцеловании в индивидуальных договорных отношениях правителя и знати находим в письме литовского князя Ольгерда константинопольскому патриарху 1371 г. с жалобой на московского князя и митрополита, что они переманивают от него князей и служилых людей, а митрополит снимает с них целование, данное Ольгерду. В качестве примеров Ольгерд ссылается на бегство от него в Москву князей Ивана Козельского и Ивана Вяземского, некоего «нагубника Василия», а также «многих других», которых митрополит «разрешает от клятвы, то есть от крестного целования» ${ }^{12}$.

Речь идёт об отношениях Литовского государства и Москвы, и это заставляет вспомнить крестоцеловальные записи, о которых уже говорилось выше. Действительно, как справедливо отметил Хартмут Рюсс, подавляющее большинство записей за кон. XV-XVI в. давались знатными людьми литовского происхождения и/или заподозренных в тайных сношениях с Литвой ${ }^{13}$. Сближают описание бегства знати в письме Ольгерда с более поздними московскими крестоцеловальными записями ещё два обстоятельства. Во-первых, Ольгерд упоминал, что верность ему бежавших в Москву его «слуг» укреплялась в своё время, кроме крестного целования, также порукой; например, по «нагубнике» Василии поручился епископ. Московские крестоцеловальные записи тоже фиксируют ручательство за опального сановника церковных иерархов, а большинство из этих записей сопровождается и поручными записями представителей высшей знати. Вовторых, про Ивана Козельского Ольгерд говорит, что тот «целовал крест ко мне со своею матерью, братьями, женою и детьми». Между тем согласно тексту образчика крестоцеловальной записи, помещённого в митрополичьем формулярнике, опальный челобитчик обязуется «детей своих больших к своему государю к великому князю привести» и самому и с ними «служити до своего живота» - то есть боярин фактически должен был целовать крест

как нижегородские бояре отступились от своего князя Бориса Константиновича и передали город татарам и московским боярам. Именно это известие послужило основанием для вывода В. И. Сергеевича о том, что, поступая на службу к князю, бояре давали «клятвенное обещание верности» (см. выше). Однако Сергеевич достаточно вольно интерпретировал рассказ об этом событии Никоновской летописи, автор которой сам явно допускал анахронизмы, по-своему перерабатывая источники, имевшиеся в его распоряжении. В частности, летописец, исходя из установившейся уже к XVI в. практики служебной присяги (о чём мы говорим ниже), посчитал, что нижегородские бояре изменили своей присяге Борису, данной в виде крестоцелования. Между тем, обращение к ранним летописям убеждает, что «крестное целование», которому «изменили» бояре, едва ли может интерпретироваться именно как клятва верности, которую каждый боярин в своё время давал князю Борису. Возможно, автор Никоновской летописи был прав, и речь шла о служебной присяге, а скорее всего вообе имелось ввиду какое-то соглашение, ранее заключённое между Борисом и нижегородцами и скреплённое крестоцелованием; см. в Рогожском летописце: ПСРЛ, т. 15, вып. 2, Пг., 1922, стб. 162-163.

12. Русская историческая библиотека, изд. 2-е, т. VI, Спб., 1909, стб. 135-140.

13. H. Rüß, op. cit., S. 270. 
не только за себя, но и за своих детей. Таким образом, как в Литве при Ольгерде, так и в Москве при Иванах III и IV и Василии III крестоцелование сопровождалось порукой, а также могло, видимо, приноситься и за детей, а может быть, и других ближайших родственников.

Как нам представляется, складывание обычая укреплять верность представителей знати крестным целованием и порукой следует относить к сравнительно позднему времени - середине или второй половине XIV в. - и связывать со специфическими обстоятельствами борьбы Москвы и Литвы за объединение русских земель, когда верность выходцев из земель, оказавшихся между Москвой и Литвой, приобрела особое значение. С кон. XIV в. двор московских князей рос, и с инкорпорацией новых земель в московское княжество его структура усложнялась. Приведение к крестному целованию служилых князей и бояр было одним из средств, которые применялись для укрепления центральной власти и для обеспечения стабильности внутри элиты (другим «стабилизирующим механизмом» было местничество, которое неслучайно начало складываться именно в XV в.). Важно, что оно имело не «договорное» происхождение, а навязывалось государственной властью силой тем, кто по каким-то причинам оказался в её глазах не заслуживающим доверия. Неслучайно возникновение обычая брать крестоцеловальные и поручные записи с высших сановников московского двора совпадает по времени с наполнением обряда крестоцелования новым содержанием: крестоцелование начинает применяться в качестве государственной присяги на верность верховному правителю.

Эта трансформация, случившаяся, очевидно, не по специальному указу, a, как это часто было в средневековой Руси, постепенно в силу общих причин (прежде всего вследствие перестройки отношений правителя и знати и перемещения акцента с идеи дружинного единения на идею подданства), довольно ясно прослеживается по летописным известиям. Именно для кон. $\mathrm{XIV}$ в. имеется первый пример, когда крестоцелование используется для присяги знати и горожан великому князю. Под 6879 (1371) г. летопись сообщает, что Дмитрий Донской, не желая передавать владимирское великое княжение Михаилу Александровичу Тверскому и опасаясь войны с ним, «по всем городом бояре и люди превел к целованию не датися князю великому Михаилу, а в землю его на княжение на великое не пустити» ${ }^{14}$. Таким образом, если ранее крестоцелование в отношениях между представителями того иного города или земли с князем использовалось только для скрепления формально равноправного договора («ряда»), то теперь речь идёт по сути о присяге подданных.

K нач. XVI в. использование крестоцелования в качестве присяги верности, навязываемой государственной властью населению, стало уже

14. ПСРЛ, т. 15, вып. 1, стб. 95. 
делом обычным и само собой разумеющимся. Это хорошо видно по летописному описанию политической ситуации, сложившейся после смерти Василия III в 1533 г. В предсмертной речи царь Василий Иванович завещал престол трёхлетнему сыну Ивану, хотя в качестве претендентов на престол - согласно древнему принципу наследования по старшинству - могли рассматриваться также младшие братья Василия Юрий и Андрей. Ни в речи умирающего царя, ни затем при возведении на престол Ивана о присяге верности «вассалов» - с крестоцелованием или без него - речь не заходит. Зато при описании политических соглашений, которые последовали после смерти великого князя, крестоцелование упоминается. Сначала бояре крестоцелованием укрепились между собой в верности завещанию Василия, т. е. признали наследником Ивана, а затем они с митрополитом «привели к кресту» на том же князей Юрия и Андрея; наконец, «к кресту» приведены были все князья и дети боярские «по градом»с обязательством служить новому великому князю ${ }^{15}$. В принципе мы имеем дело здесь с обычной ситуацией в том случае, когда решается судьба престола после смерти князя и нарушается традиционный порядок престолонаследия (от старшего брата к младшим). Однако крестоцелование используется при этом не только традиционно - то есть как клятва, скрепляющая некое (политическое) соглашение (укрепление крестом бояр между собой), - но и с новым значением: как присяга верности (приведение к кресту Юрия и Андрея и всего служилого класса «по градом»). И не может быть никаких сомнений в том, что это - не клятва вассала сюзерену частноправового характера, а государственная служебная (публично-правовая) присяга.

В целом, таким образом, вырисовывается довольно сложная картина применения крестоцелования в политической практике на Руси в XIV нач. XVI в. С одной стороны, именно в этот период с формированием новой политической системы московского самодержавия оно приобретает новую функцию, а именно: используется для служебной присяги знати и вообще всего служилого класса правителю. По-видимому, приведение к присяги служилых людей в более или менее массовом порядке ещё не обрело регулярного, юридически обоснованного характера, а применялось эпизодически в тех случаях, когда власть ощущала нестабильность и угрозу - например, когда при смене правителя наследник не мог взять твёрдо бразды правления в свои руки и нуждался в специальной поддержке правящего класса.

C другой стороны, приблизительно с кон. XIV - нач. XV в. крестоцелование начинает использоваться московским правительством для закрепления обязательства отдельных представителей знати не оставлять службу великому князю. Следует подчеркнуть исключительный характер

15. См. в Воскресенской летописи (ПСРЛ, т. 8, с. 285-286) и в Пискарёвском летописце (Материалы по истории СССР, т. II, М., 1950, с. 24). 
случаев, когда давались такие обязательства - все они связаны со специфическими обстоятельствами борьбы Московского княжества и Великого княжества Литовского за объединение русских земель. «Укреплялась» верность только отдельных сановников, заподозренных в измене. Причём первостепенное значение в этом «укреплении» имело не крестоцелование само по себе, а ручательство за опального сановника, оказавшегося в «вине» перед московским государем, высших лиц светской и духовной иерархии.

Эти наблюдения заставляют усомниться в справедливости сравнения русского средневекового крестоцелования с западноевропейскими обрядами вступления в вассалитет и трактовки его как присяги верности знатного «вассала» князю. Государственная служебная присяга в принципе не может быть сопоставима с вассалитетом: одно - это явление публичного права, связанное со становлением централизованного государства и идеей подданства, другое - обычай, выросший из идеи частного договора и расцветший именно в условиях дефицита и слабости государственной власти. Приведение к кресту знатных людей, заподозренных в измене московскому князю, с взиманием с них «укрепленых записей» также имеет мало общего с вассальной клятвой. Об этом говорит многое: принудительный, а не добровольный, характер обязательств, поручительство иерархов и сановников, целование креста с родственниками, но главное - оформление всей процедуры как акта пожалования «государя» провинившемуся перед ним «слуге». Это последнее прежде всего и не позволяет говорить, что записи отражают какие-либо «договорные отношения». Хотя крестоцеловальные записи взимались индивидуально и в них присутствует частноправовой элемент, но скрепляли они не договор, а обязательство подданного (а не вассала) безоговорочно и беззаветно (как стали говорить позднее - «верой и правдой») служить суверенному правителю (а не сюзерену).

Российская Академия Наук

Институт российской истории

petr_stefanovich@hotmail.com 